\title{
Forensic Dentistry - the key to the truth
}

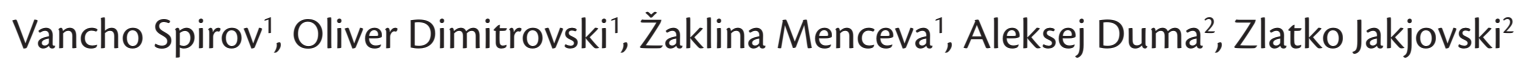 \\ 'University Dental Clinical Centre „St. Pantelejmon“, Department of Oral Surgery, Skopje, Republic of Macedonia; \\ ${ }^{2}$ Institute of Forensic medicine, Criminology and Medical deontology, Skopje, Republic of Macedonia
}

\begin{abstract}
SUMMARY
Introduction Human organism can be identified through testing and analysis of DNA sequences. The most common source of DNA for analysis is blood, soft tissues, hair, bones and teeth. Teeth represent a tissue of choice for analysis in those cases where there is high degree of degradation of other tissues. Hard tooth structure provides protection and preservation of DNA molecules.

The aim was to investigate which group of teeth and dental tissue (pulp or hard dental tissues) has the greatest amount of DNA.

Material and method Forty-five extracted teeth were analyzed. In the first examination 30 teeth were divided into the three groups (10 teeth each): first group were incisors, second premolars and third molars. The teeth were measured before and after the procedure of DNA isolation using special scale with precision of 0.02-0.000005ng. The procedure included grinding teeth in a blender and DNA isolation using commercial kits (isolation with magnetic particles). For the second test 15 teeth divided into two groups were used. In the first group isolation of DNA molecules was performed from pulp tissue, and in the second group from hard dental tissues. The quantification of samples was done with Quantifiler ${ }^{\circledR}$ Duo DNA Quantification Kit by Applied Biosystems.

Results The greatest amount of DNA was obtained from molars $(0.230011 \mathrm{ng} / \mu \mathrm{l} / \mathrm{g})$ while the smallest amount of DNA was obtained from incisors and it was $0.06437 \mathrm{ng} / \mu \mathrm{l} / \mathrm{g}$. In addition, the amount of DNA isolated from pulp tissue was significantly greater than that from hard dental tissues (pulp of molars obtained quantitatively the largest amount of DNA).

Conclusion Main tissue to be used for the isolation of DNA from a tooth is pulp, but in those cases when it is not present (endodontic treatment), hard dental tissues provide sufficient quantity of DNA for identification procedures. The group of teeth that provides the greatest amount of DNA is molars.
\end{abstract}

Keywords: DNA isolation; molars; dento-pulp complex

\section{INTRODUCTION}

Forensic dentistry represents a scientific discipline in which field of interest is the tooth and all its features, starting with its morphology and analysis of its structural components, in order to get information to solve criminal cases or use in court (legal) system. Forensic odontology or Forensic dentistry is defined by Keiser-Neilson in 1970 [1] as "the branch of forensic medicine that in the interest of legal system handles and examines dental evidence and appropriately evaluates and presents dental findings". The most common role of forensic dentist is identification of deceased individuals [2]. Dental identification includes two modes. The first one is comparative identification used to verify that the remains of a deceased person and the person represented by dental data obtained before death (antemortem) are one and the same individual. The second method includes cases where data before death (antemortem) does not exist. In that case, forensic dentist complete data after death (postmortem) obtaining the deceased person's individual characteristics in order to compare them with antemortem data. This process is called postmortem dental profiling.
Human body can also be identified through testing and analysis of DNA sequences. Each cell of an individual contains multiple DNA copies. Every human being is characterized by a unique (single) DNA sequence due to hypervariable regions of DNA that are specific for that person. The sequence of DNA molecules called base pairs (bp) in each individual varies with the exception of identical twins and is called sequence polymorphism. Length polymorphism as AATG-AATG (repeat twice), or AATGAATG-AATG (triple repetition), called Short Tandem Repeats (STR) is used in forensic identification [3,4]. These repetitive sequences are called DNA fingerprints and the procedure for their identification is called DNA typifying, i.e. profiling (DNA Profiling). DNA profiling represents standard procedure in forensic system for human identification, criminal cases and determining fatherhood [5].

Beside DNA isolation from hair, bones, dried soft tissue, teeth give best usable DNA for identification because of the hard dental tissue that physically protects the pulp. Most often tissue used for the isolation of DNA is pulp tissue, which is connective tissue composed of cells (odontoblasts, fibroblasts, endothelial cells, peripheral nerves, undefined mesenchymal cells, macrophages and 
lymphocytes). However, in cases of endodontically treated tooth, where pulp is removed, DNA may be extracted from calcified tissue, dentin or dentin and cement together by the milling procedure to produce powder. DNA isolation is also possible from periodontal fibers and attached periodontal bone fragments.

The quality and quantity of extracted DNA from teeth depends on several external and individual factors. From individual factors, special attention is given to the volume of pulp chamber that is different in different teeth groups. Like for other tissues, DNA isolation from teeth depends on external influences like temperature, time of death, humidity, bacterial and fungal contamination $[6,7]$. Also, the fastest DNA molecule degradation occurs in the first two years, depending on external and personal factors [6].

The aim was to investigate which group of teeth and dental tissue (pulp or hard dental tissues) has the greatest amount of DNA.

\section{MATERIAL AND METHODS}

Forty-five extracted teeth without major caries damage (in vitro study) extracted at the Clinic for Oral Surgery at the University Dental Clinical Center-St.Pantelejmon in Skopje were analyzed. DNA analyses were conducted at the Institute of forensic medicine, Criminology and Medical deontology. The method with magnetic particles as solid phase for binding the DNA molecule was used (Prepfiler Kit from ABI ${ }^{\mathrm{mm}}$ ).

This technique of DNA isolation (unlike the old process of organic isolation) is based on solid phase extraction (SPE). It uses columns filled with silica (or other solid phase) that selectively bind (adsorb) nucleic acids (DNA or RNA) depending on the environmental $\mathrm{pH}$ and concentration of salt in the buffer (in our case the solid phase were magnetic particles). The columns and all buffers used to perform the procedure come in the form of commercial kits and the procedure was performed according to the manufacturer's instructions.

Quantification of samples was performed using the Quantifiler DNA Quantification Kit (Applied Biosystems) on 7500 Real Time PCR System. This approach allows DNA quantification in the initial sample by measuring the fluorescence signals during amplification of the targeted sequence. The primary objective of the Real Time PCR quantification is determining "amplifiable" DNA present in the sample. The input amount of Quantifiler ${ }^{\circ}$ Duo Primer Mix for quantification of one sample was $10.5 \mu \mathrm{l}$, and the input amount of Quantifiler ${ }^{\circledR}$ Duo PCR Reaction Mix for quantification of one sample was $12.5 \mu \mathrm{l}$. The volume of a sample added into the reaction for quantification was $2 \mu \mathrm{l}$. The full volume of a reaction mix was $25 \mu \mathrm{l}$.

The first examination comprised 30 teeth divided into the three groups of 10 teeth: incisors, premolars and molars. The procedure of DNA isolation from teeth included teeth grinding in a blender and use of commercialized kits (isolation with magnetic particles). With this method, teeth that had previously done endodontic treatment could not be used for DNA isolation [8]. First, the teeth were rinsed under the tap water and surface was well cleaned with a scalpel and a brush. In addition, the teeth were kept in ultrasonic bath in $1 \%$ sodium hypochlorite $(\mathrm{NaOCl})$ twice for 10 minutes with replacement of $\mathrm{NaOCl}$ solution. This procedure was repeated also twice with distilled water. The cleaning procedure took about 40 minutes. The teeth were placed then in a fume cupboard to dry overnight. Dried teeth were weight first and then ground in a blender for small bones and teeth to obtain tooth powder.

For the second test 15 teeth divided into two groups were used. In the first group isolation of DNA molecules was performed from the pulp tissue, and in the second group the same teeth that pulp was collected from were grinded and used for DNA isolation. Pulp was collected using nerve extirpators after performed horizontal sectioning of the tooth. This procedure of horizontal separation of the tooth in the line of the neck of the tooth was done in order to preserve occlusal surface of the tooth that can serve for further procedure of identification. This separation was done using diamond burs and micro motor. The bur was moved around the teeth in circular motions. When close to pulp chamber, teeth were split with lever, to avoid overheating and mechanical damage of pulp tissue, and thus contamination of the material.

\section{RESULTS}

In our first test the analysis and comparison of different groups of teeth, freshly extracted incisors, premolars and molars was done. Those are three groups differing in size and number of roots, i.e. there are large morphological differences between them. The results are shown in Tables 1-3.

In the second test the amount of DNA obtained from the pulp and hard dental tissues was compared. The results are shown in the Tables 4-5.

\section{DISCUSSION}

In forensic cases of identification, where human remains are extremely damaged or degraded, teeth and bones are often the only source of DNA $[9,10]$. Genetic analysis of teeth depends on the amount of DNA present, the level of degradation and efficiency of the collecting processes of DNA and methods used for DNA isolation [11]. With the current knowledge about the structure of teeth and after death degradation of DNA in dental tissue, our paper offers optimal selection of teeth, in order to increase the effectiveness of DNA extraction and DNA profiling.

It can be seen that the greatest amount of DNA was obtained is in the group three or group of molars and it was $0.230011 \mathrm{ng} / \mu \mathrm{l} / \mathrm{g}$ tooth, while the smallest amount of isolated DNA was obtained in the first group, i.e. the incisors and it was $0.06437 \mathrm{ng} / \mu \mathrm{l} / \mathrm{g}$ tooth. The concentration of isolated DNA from the group of molars was four times greater than group of premolar and five times than group of incisors. Comparison of the first and second group, i.e. group of premolars and incisors indicated 
Table 1. Quantity of isolated DNA from solid dental tissue from group of incisors

Tabela 1. Količina izolovane DNK iz čvrstog zubnog tkiva iz grupe sekutića

\begin{tabular}{|c|c|c|c|c|}
\hline \multicolumn{5}{|c|}{$\begin{array}{l}\text { Amount of DNA isolated from the dental tissue } \\
\text { Količina DNK izolovana iz zubnog tkiva }\end{array}$} \\
\hline & $\begin{array}{l}\text { Weight of } \\
\text { the tooth } \\
\text { (g) } \\
\text { Težina } \\
\text { zuba (g) }\end{array}$ & $\begin{array}{c}\text { Type of } \\
\text { the tooth } \\
\text { Vrsta } \\
\text { zuba }\end{array}$ & $\begin{array}{l}\text { DNA concen- } \\
\text { tration }(n g / \mu \mathrm{l}) \\
\text { Koncentracija } \\
\text { DNK }(n g / \mu \mathrm{l})\end{array}$ & $\begin{array}{c}\text { DNA concentra- } \\
\text { tion per gram of } \\
\text { the tooth }(\mathrm{ng} / \\
\mu \mathrm{l} / \mathrm{g}) \\
\text { Koncentracija } \\
\text { DNK po gramu } \\
\text { zuba }(\mathrm{ng} / \mu \mathrm{l} / \mathrm{g})\end{array}$ \\
\hline 1. & 0.52 & $\begin{array}{l}\text { Incisor } \\
\text { Sekutić }\end{array}$ & 0.0160 & 0.030769 \\
\hline 2. & 0.29 & $\begin{array}{l}\text { Incisor } \\
\text { Sekutić }\end{array}$ & 0.0451 & 0.155517 \\
\hline 3. & 1.33 & $\begin{array}{l}\text { Incisor } \\
\text { Sekutić }\end{array}$ & 0.0124 & 0.009323 \\
\hline 4. & 1.24 & $\begin{array}{l}\text { Incisor } \\
\text { Sekutić }\end{array}$ & 0.0585 & 0.047177 \\
\hline 5. & 0.10 & $\begin{array}{l}\text { Incisor } \\
\text { Sekutić }\end{array}$ & 0.00216 & 0.0216 \\
\hline 6. & 0.57 & $\begin{array}{l}\text { Incisor } \\
\text { Sekutić }\end{array}$ & 0.0210 & 0.036842 \\
\hline 7. & 1.01 & $\begin{array}{l}\text { Incisor } \\
\text { Sekutić }\end{array}$ & 0.0531 & 0.052574 \\
\hline 8. & 0.13 & $\begin{array}{l}\text { Incisor } \\
\text { Sekutić }\end{array}$ & 0.0224 & 0.172307 \\
\hline 9. & 0.62 & $\begin{array}{l}\text { Incisor } \\
\text { Sekutić }\end{array}$ & 0.0635 & 0.102419 \\
\hline 10. & 0.24 & $\begin{array}{l}\text { Incisor } \\
\text { Sekutić }\end{array}$ & 0.00366 & 0.01525 \\
\hline $\begin{array}{l}\text { Average } \\
\text { Srednja } \\
\text { vrednost }\end{array}$ & 0.605 & & 0.0297 & 0.06437 \\
\hline
\end{tabular}

Table 2. Quantity of isolated DNA from solid dental tissue from group of premolars

Tabela 2. Količina izolovane DNK iz čvrstog zubnog tkiva iz grupe premolara

\begin{tabular}{|c|c|c|c|c|}
\hline \multicolumn{5}{|c|}{$\begin{array}{l}\text { Amount of DNA isolated from the dental tissue } \\
\text { Količina DNK izolovana iz zubnog tkiva }\end{array}$} \\
\hline & $\begin{array}{c}\text { Weight of } \\
\text { the tooth } \\
\text { (g) } \\
\text { Težina } \\
\text { zuba (g) }\end{array}$ & $\begin{array}{c}\text { Type of } \\
\text { the tooth } \\
\text { Vrsta } \\
\text { zuba }\end{array}$ & $\begin{array}{l}\text { DNA concen- } \\
\text { tration }(n g / \mu \mathrm{l}) \\
\text { Koncentracija } \\
\text { DNK }(\mathrm{ng} / \mu \mathrm{l})\end{array}$ & $\begin{array}{c}\text { DNA concentra- } \\
\text { tion per gram of } \\
\text { the tooth (ng/ } \\
\mu \mathrm{l} / \mathrm{g}) \\
\text { Koncentracija } \\
\text { DNK po gramu } \\
\text { zuba }(\mathrm{ng} / \mu \mathrm{l} / \mathrm{g})\end{array}$ \\
\hline 1. & 0.76 & premolar & 0.0115 & 0.015132 \\
\hline 2. & 1.02 & premolar & 0.0548 & 0.053725 \\
\hline 3. & 1.13 & premolar & 0.0514 & 0.045487 \\
\hline 4. & 1.00 & premolar & 0.0321 & 0.0321 \\
\hline 5. & 0.25 & premolar & 0.0345 & 0.138 \\
\hline 6. & 0.63 & premolar & 0.0965 & 0.153174 \\
\hline 7. & 0.92 & premolar & 0.0628 & 0.068260 \\
\hline 8. & 1.04 & premolar & 0.0614 & 0.059038 \\
\hline 9. & 1.42 & premolar & 0.0971 & 0.068380 \\
\hline 10. & 0.75 & premolar & 0.0496 & 0.066133 \\
\hline $\begin{array}{l}\text { Average } \\
\text { Srednja } \\
\text { vrednost }\end{array}$ & 0.892 & & 0.04116 & 0.069942 \\
\hline
\end{tabular}

Table 3. Quantity of isolated DNA from solid dental tissue from group of molars

Tabela 3. Količina izolovane DNK iz čvrstog zubnog tkiva iz grupe premolara

\begin{tabular}{|c|c|c|c|c|}
\hline \multicolumn{5}{|c|}{$\begin{array}{l}\text { Amount of DNA isolated from the dental tissue } \\
\text { Količina DNK izolovana iz zubnog tkiva }\end{array}$} \\
\hline & $\begin{array}{l}\text { Weight of } \\
\text { the tooth } \\
\text { (g) } \\
\text { Težina } \\
\text { zuba (g) }\end{array}$ & $\begin{array}{l}\text { Type of } \\
\text { the tooth } \\
\text { Vrsta } \\
\text { zuba }\end{array}$ & $\begin{array}{l}\text { DNA concen- } \\
\text { tration }(n g / \mu \mathrm{l}) \\
\text { Koncentracija } \\
\text { DNK }(n g / \mu \mathrm{l})\end{array}$ & $\begin{array}{c}\text { DNA concentra- } \\
\text { tion per gram of } \\
\text { the tooth }(\mathrm{ng} / \\
\mu \mathrm{l} / \mathrm{g}) \\
\text { Koncentracija } \\
\text { DNK po gramu } \\
\text { zuba }(\mathrm{ng} / \mu \mathrm{l} / \mathrm{g})\end{array}$ \\
\hline 1. & 2.31 & molar & 0.0169 & 0.007316 \\
\hline 2. & 2.64 & molar & 0.2050 & 0.077652 \\
\hline 3. & 1.63 & molar & 0.0126 & 0.00773 \\
\hline 4. & 2.02 & molar & 0.0976 & 0.048317 \\
\hline 5. & 1.55 & molar & 1.04 & 1.890909 \\
\hline 6. & 1.62 & molar & 0.0219 & 0.013518 \\
\hline 7. & 1.84 & molar & 0.2130 & 0.115760 \\
\hline 8. & 0.92 & molar & 0.0228 & 0.024782 \\
\hline 9. & 1.14 & molar & 0.0926 & 0.081228 \\
\hline 10. & 1.38 & molar & 0.0454 & 0.032898 \\
\hline $\begin{array}{l}\text { Average } \\
\text { Srednja } \\
\text { vrednost }\end{array}$ & 1.705 & & 0.17678 & 0.230011 \\
\hline
\end{tabular}

approximately the same concentration of isolated DNA, with slightly more from the group of premolars. This can be explained by the fact that premolars have variations in the crown size and number of roots (one or two roots). Positive correlation was found between the tooth weight and the amount of isolated DNA. The lowest weight had incisors with average of $0.605 \mathrm{~g}$, and they gave the least amount of isolated DNA. Then, premolars had average of $0.892 \mathrm{~g}$, and they provided more isolated DNA, while molars weighing $1.705 \mathrm{~g}$ gave the greatest amount of isolated DNA. Other studies that compared the amount of DNA between different types of teeth showed that teeth with the largest quantity of dental tissue are the best source of DNA $[11,7]$. It has also been confirmed that greater amount of DNA can be obtained from teeth with more roots and this is due to the larger root surface that provides greater amount of cement [11].

Teeth with more roots not only have larger root area and higher amount of pulp tissue in which odontoblasts and cementocites are located, but also show more cellular cement, compared to other groups of teeth, which in some cases have little or no cellular cement. Therefore, molars would be teeth of choice of tooth for DNA sampling due to the largest surface area of the root. In the absence of molars, premolars are recommended for DNA isolation, because they have greater amount of cellular cement than anterior teeth, but canine would have larger volume of pulp. Greater amount of cellular cement provides greater number of cementocites, cells that are the main source of DNA.

In the second part of the study, it was shown that the amount of DNA obtained from the pulp was significantly higher than the amount of DNA obtained from hard dental tissues. The amount of DNA obtained from the pulp, by different groups of teeth, indicated that the group of 
Table 4. Quantity of isolated DNA from hard dental tissue Tabela 4. Količina izolovane DNK iz čvrstog zubnog tkiva

\begin{tabular}{|c|c|c|c|c|}
\hline \multicolumn{5}{|c|}{ Group 2. Amount of DNA isolated from the dental pulp } \\
\hline & $\begin{array}{l}\text { Weight } \\
\text { of the } \\
\text { tooth }(\mathrm{g})\end{array}$ & $\begin{array}{l}\text { Type of } \\
\text { the tooth }\end{array}$ & $\begin{array}{c}\text { DNA } \\
\begin{array}{c}\text { concentration } \\
(n g / \mu l)\end{array}\end{array}$ & $\begin{array}{l}\text { DNA conc. per } \\
\text { gram of the thooth } \\
\text { ( } \mathrm{ng} / \mu \mathrm{l} / \mathrm{g} \text { of tooth) }\end{array}$ \\
\hline 1. & 0,52 & incisor & 0,0160 & 0,030769 \\
\hline 2. & 0,29 & incisor & 0,0451 & 0,155517 \\
\hline 3. & 1,33 & incisor & 0,0124 & 0,009323 \\
\hline 4. & 1,24 & incisor & 0,0585 & 0,047177 \\
\hline 5. & 0,10 & incisor & 0,00216 & 0,0216 \\
\hline \multicolumn{3}{|c|}{$\begin{array}{l}\text { Average } \\
\text { Srednja vrednost }\end{array}$} & Av. 0,0268 & Av. 0,05287744 \\
\hline 1. & 0,76 & premolar & 0,0115 & 0,015132 \\
\hline 2. & 1,02 & premolar & 0,0548 & 0,053725 \\
\hline 3. & 1,13 & premolar & 0,0514 & 0,045487 \\
\hline 4. & 1,00 & premolar & 0,0321 & 0,0321 \\
\hline 5. & 0,25 & premolar & 0,0345 & 0,138 \\
\hline \multicolumn{3}{|c|}{$\begin{array}{l}\text { Average } \\
\text { Srednja vrednost }\end{array}$} & Av. 0,0369 & Av. 0,056888759 \\
\hline 1. & 2,31 & molar & 0,0169 & 0,007316 \\
\hline 2. & 2,64 & molar & 0,2050 & 0,077652 \\
\hline 3. & 1,63 & molar & 0,0126 & 0,00773 \\
\hline 4. & 2,02 & molar & 0,0976 & 0,048317 \\
\hline 5. & 0,55 & molar & 1,04 & 1,890909 \\
\hline \multicolumn{3}{|c|}{$\begin{array}{l}\text { Average } \\
\text { Srednja vrednost }\end{array}$} & Av. 0,2744 & Av. 0,406384703 \\
\hline
\end{tabular}

Table 5. Quantity of isolated DNA from pulp tissue Tabela 5. Količina izolovane DNK iz pulpnog tkiva

\begin{tabular}{|c|c|c|c|c|}
\hline \multicolumn{5}{|c|}{ Group 2. Amount of DNA isolated from the dental pulp } \\
\hline & $\begin{array}{l}\text { Weight } \\
\text { of the } \\
\text { tooth }(\mathrm{g})\end{array}$ & $\begin{array}{c}\text { Type of } \\
\text { the tooth }\end{array}$ & $\begin{array}{c}\text { DNA } \\
\text { concentration } \\
(\mathrm{ng} / \mu \mathrm{l})\end{array}$ & $\begin{array}{l}\text { DNA conc. per } \\
\text { gram of the thooth } \\
\text { ( } \mathrm{ng} / \mu \mathrm{\mu l} / \mathrm{g} \text { of tooth) }\end{array}$ \\
\hline 1. & 0,01195 & incisor & 0,01860 & 1,55649 \\
\hline 2. & 0,01049 & incisor & 0,06300 & 6,00572 \\
\hline 3. & 0,00132 & incisor & 0,02020 & 2,67905 \\
\hline 4. & 0,00282 & incisor & 0,00568 & 2,014418 \\
\hline 5. & 0,00725 & incisor & 0,10200 & 14,06897 \\
\hline \multicolumn{3}{|c|}{$\begin{array}{l}\text { Average } \\
\text { Srednja vrednost }\end{array}$} & Av. 0,04190 & Av. 26,32441 \\
\hline 1. & 0,00812 & premolar & 0,02450 & 3,01724 \\
\hline 2. & 0,01700 & premolar & 0,06980 & 4,10588 \\
\hline 3. & 0,01658 & premolar & 0,03360 & 2,02654 \\
\hline 4. & 0,00754 & premolar & 0,07570 & 57,34848 \\
\hline 5. & 0,01026 & premolar & 0,01510 & 1,47173 \\
\hline \multicolumn{3}{|c|}{$\begin{array}{l}\text { Average } \\
\text { Srednja vrednost }\end{array}$} & Av. 0,04374 & Av. 67,96987 \\
\hline 1. & 0,02808 & molar & 0,09440 & 3,506 \\
\hline 2. & 0,00988 & molar & 0,31800 & 0,348 \\
\hline 3. & 0,01098 & molar & 0,98200 & 8,600 \\
\hline 4. & 0,01856 & molar & 0,01850 & 0,863 \\
\hline 5. & 0,01098 & molar & 0,03010 & 0,021 \\
\hline \multicolumn{3}{|c|}{$\begin{array}{l}\text { Average } \\
\text { Srednja vrednost }\end{array}$} & Av. $\mathbf{0 , 2 8 8 6 0}$ & Av. 128,72151 \\
\hline \multicolumn{5}{|c|}{ Average DNA conc. from pulps } \\
\hline
\end{tabular}

molars quantitatively provides the largest amount of DNA. This is due to the fact that pulp tissue of molars has the largest number of present cells that are major source of DNA (Table 5).

The quantity of DNA obtained from pulp complex of three different groups of teeth, showed that molars provided the largest amount of DNA. That was expected, as the volume of pulp chamber in molars is the largest. Group of premolars and incisors provided similar amount of isolated DNA that was six times smaller than from the group of molars. Similarly, the amount of DNA isolated from hard dental tissues was significantly higher in the group of molars than the other two groups (premolars and incisors) that were similar. Comparing the amount of isolated DNA $(\mathrm{ng} / \mu \mathrm{l} / \mathrm{g})$ from pulp and hard dental tissue showed that pulp provided 85 times higher amount of DNA.

Dentin / pulp complex constitutes the bulk of the tooth, and unlike the enamel, is highly complex cellular tissue. The pulp is rich vascularized and innervated, and contains connective tissue with various types of cells. These include odontoblasts (cells that produce dentin), fibroblasts, defense cells (macrophages and histocytes), plasma cells, nerve cells, undifferentiated mesenchymal cells [12]. Knowing that about 80 diploid cells are sufficient to provide a minimum amount of DNA required for STR mapping, it can be concluded that the pulp is an extremely valuable source of DNA. Pulp complex is in connection with periodontal tissues (tissues that connect any tooth to the alveolar bone) over the top of the root, and through accessory canals [13].

\section{CONCLUSION}

Pulp tissue and cement are clearly the most valuable sources of nuclear DNA from the tooth. Enamel protects dentin and pulp, but has no DNA. Main tissue that should be used for DNA isolation is pulp, but in those cases where it is not present (endodontic treatment), hard dental tissues provide sufficient quantity of DNA for identification procedures. The group of teeth that provides the greatest amount of DNA is molars.

\section{REFERENCES}

1. Keiser-Neilsen S. Person Identification by Means of Teeth. Bristol: John Wright \& Sons; 1980.

2. Jones DG. Odontology often is final piece to grim puzzle. J Calif Dent Assoc. 1998; 26:650-3. [PMID: 9879231]

3. Manjunath BC, Chandrashekhar BR, Mahesh M, Vatchala Rani RM. DNA profiling and forensic dentistry - A review of the recent concepts and trends. J Forensic Leg Med. 2011; 18:191-7. [DOI: 10.1016/j. jflm.2011.02.005] [PMID: 21663865]

4. Butler JM. Forensic DNA typing: Biology, technology and genetics of STR markers. San Diego: Academic Press; 2005.

5. Buckleton J, Triggs CM, Walsh SJ. Forensic DNA evidence interpretation. Washington, D.C: CRC Press; 2005.

6. O'Rourke DH, Hayes MG, Shawn WC. Ancient DNA studies in physical anthropology. Annu Rev Antrop. 2000; 29:217-42. 
7. De Leo D, Turrina S, Marigo M. Effects of individual dental factors on Genomic DNA Analysis. Am J Forensic Med Pathol. 2000; 21:411-5. [PMID: 11111808]

8. Corte-Real AT, Anjos MJ, Addrade M. Genetic identification in endodontic treated tooth root. Forencis Sci Int. Genetics Supplement Series 01/2008; 1:457-8. [DOI: 10.1016/j.fsigss.2007.10.094]

9. Smith BC, Fisher DL, Weedn VW, Warnock GR, Holland MM. A systematic approach to the sampling of dental DNA. J.Forensic Sci. 1993; 38:1194-209. [PMID: 8228888]

10. Malaver PC, Yunis J]. Different dental tissues as a source of DNA for human identification in forensic cases. Croat Med J. 2003; 44:306-9. [PMID: 12808723]

11. Rubio L, Martinez LJ, Martinez E, Martin de las Hernas S. Study of short and long term storage of teeth and its influence on DNA. J
Forensic Sci. 2009; 54:1411-3. [DOI: 10.1111/j.1556-4029.2009.01159.x] [PMID: 19804532]

12. Chiego DJ. Histology of the pulp. In: Avery JK, Steele PF, Avery N (Eds.). Oral Development and Histology, New York: Thieme Medical Publishers; 2002. p. 190-212.

13. Vertucci FJ, Anthony RL. A scanning electron microscopic investigation of accessory foramina in the furcation and pulp chamber floor of molar teeth. Oral Surg Oral Med Oral Pathol. 1986; 62(3):319-26. [PMID: 3462636]

Received: 13.06.2017 • Accepted: 29.08.2017 


\title{
Forenzička stomatologija - ključ do istine
}

\author{
Vančo Spirov ${ }^{1}$, Oliver Dimitrovski', Žaklina Menceva', Aleksej Duma², Zlatko Jakjovski² \\ "Univerzitetski stomatološki klinički centar „St. Pantelejmon", Klinika za oralnu hirurgiju, Skoplje, Makedonija; \\ ${ }^{2}$ Institut za sudsku medicinu, kriminologiju i medicinsku deontologiju, Skoplje, Makedonija
}

\begin{abstract}
KRATAK SADRŽAJ
Uvod Ljudski organizam se može identifikovati kroz testiranje i analizu sekvenci DNK. Najčešći izvor DNK za analizu su krv, meko tkivo, kosa, kosti i zubi. Zubi predstavljaju izbor tkiva za analizu u onim slučajevima u kojima postoji visok stepen degradacije drugih tkiva. Čvrsta zubna struktura pruža zaštitu i očuvanje molekula DNK.

Cilj je bio da se istraži koja grupa zuba i zubnog tkiva (pulpa ili tvrda zubna tkiva) ima najveću količinu DNK.

Materijal i metod Analizirano je 45 ekstrahovanih zuba. U prvom ispitivanju 30 zuba podeljeno je u tri grupe (svaka po 10 zuba): prva grupa su bili sekutići, druga premolari i treća molari. Zubi su mereni pre i nakon postupka izolacije DNK korišćenjem specijalne vage sa preciznošću 0,02-0,000005 ng. Postupak je obuhvatio mlevenje zuba u blenderu i izolaciju DNK pomoću komercijalnih kompleta (izolacija magnetnim česticama). Za drugo ispitivanje analizirano je 15 zuba podeljenih u dve grupe. U prvoj grupi urađena je izolacija molekula DNK iz zubne pulpe, a u drugoj grupi iz tvrdih zubnih tkiva. Kvantifikacija uzoraka napravljena je pomoću Quantifiler ${ }^{\oplus}$ Duo DNA Quantification Kita (Applied Biosystems).

Rezultati Najveća količina DNK dobijena je iz molara $(0,0230011 \mathrm{ng} / \mu \mathrm{l} / \mathrm{g})$, dok je najmanja količina DNK dobijena u prvoj grupi (sekutići) i iznosila je $0,06437 \mathrm{ng} / \mu \mathrm{l} / \mathrm{g}$. Takođe, količina DNK izolovane iz tkiva pulpe je bila značajno veća nego iz tvrdih zubnih tkiva (iz pulpnog tkiva kutnjaka dobijena je kvantitativno najveća količina DNK).

Zaključak Glavno tkivo koje treba koristiti za izolaciju DNK iz zuba je pulpa, ali u onim slučajevima kada nije prisutna (endodontski tretman) tvrda tkiva obezbeđuju dovoljnu količina DNK za postupke identifikacije. Grupa zuba koja pruža najveću količinu DNK su kutnjaci.

Ključne reči: DNK izolacija; kutnjaci; pulpodentinski kompleks
\end{abstract}

\section{UVOD}

Forenzička stomatologija predstavlja naučnu disciplinu čiji su interes zub i sve njegove karakteristike, počev od morfologije i analize njegovih strukturnih komponenti, kako bi se dobile informacije za rešavanje krivičnih predmeta ili korišćenje u sudskom (pravnom) sistemu. Forenzička odontologija ili forenzička stomatologija definisana je od strane Keizer-Neilsona 1970. [1] kao ,grana forenzičke medicine koja u interesu pravnog sistema analizira i ispituje stomatološke dokaze i na odgovarajući način ocenjuje i predstavlja nalaze“. Najč̌šća uloga forenzičkog zubara je identifikacija preminulih osoba [2]. Identifikacija zuba može biti urađena na dva načina. Prvi je komparativna identifikacija, koja se koristi da bi se utvrdilo da su posmrtni ostaci umrlog lica i osoba koja je predstavljena zubnim podacima dobijenim pre smrti (antemortem) jedna ista osoba. Druga metoda obuhvata slučajeve gde podaci pre smrti (antemortem) ne postoje. $\mathrm{U}$ tom slučaju forenzički zubar završava podatke nakon smrti (postmortem) tako što dobija individualne karakteristike pokojnika kako bi ih uporedio sa antemortemskim podacima. Ovaj proces se naziva postmortem zubno profiliranje.

Ljudsko telo se takođe može identifikovati kroz testiranje i analizu sekvenci DNK. Svaka ćelija pojedinca sadrži više kopija DNK. Svako ljudsko biće karakteriše jedinstvena (pojedinačna) DNK sekvenca zbog hipervarijabilnih regiona DNK koji su specifični za tu osobu. Sekvence molekula DNK koje se nazivaju bazni parovi (bp) u svakom pojedincu variraju, sa izuzetkom identičnih blizanaca, $i$ to se naziva polimorfizam sekvence. Dužina polimorfizma kao AATG-AATG (ponovljena dva puta), ili AATG-AATG-AATG (trostruko ponavljanje), pod nazivom Kratko tandem ponavljanje (STR), koristi se u forenzičkoj identifikaciji $[3,4]$. Ove ponavljajuće sekvence se zovu DNK otisci prstiju, a postupak njihove identifikacije naziva se tipizacijom, tj. profiliranjem DNK. To je standardna procedura u forenzičkom sistemu za identifikaciju ljudi, krivične slučajeve i utvrđivanje očinstva [5].

Pored izolacije DNK iz kose, kostiju ili osušenog mekog tkiva, zubi daju najbolje iskoristivu DNK za identifikaciju zbog tvrdog zubnog tkiva koji fizički štiti pulpu. Tkivo koje se najčešće koristi za izolaciju DNK je tkivo pulpe i ono predstavlja vezivno tkivo sastavljeno od ćelija (odontoblasta, fibroblasta, endotelnih ćelija, perifernih živaca, nedefinisanih mezenhimalnih ćelija, makrofaga i limfocita). Međutim, u slučajevima gde je endodontski tretman obavljan na zubu i pulpa uklonjena, DNK se može ekstrahovati iz kalcificiranog tkiva, dentina ili dentina i cementa zajedno postupkom mlevenja kako bi se proizveo prah. DNK izolacija je takođe moguća od parodontalnih vlakana i spojenih parodontalnih fragmenata kostiju.

Kvalitet i količina ekstrahovane DNK iz zuba zavisi od nekoliko spoljašnjih i pojedinačnih faktora. Od pojedinačnih faktora posebna pažnja se daje zapremini komore pulpe, koja je različita u različitim grupama zuba. Kao i za druga tkiva, izolacija DNK iz zuba zavisi od spoljnih uticaja kao što su temperatura, vreme smrti, vlažnost, bakterijska i gljivična kontaminacija [6, 7]. Takođe, najbrža degradacija molekula DNK dešava se u prve dve godine, u zavisnosti od spoljašnjih i pojedinačnih faktora [6].

Cilj ovog rada je bio da se ispita koja grupa zuba i zubnog tkiva (pulpa ili tvrda zubna tkiva) ima najveću količinu DNK.

\section{MATERIJAL I METOD}

Analizirano je 45 intaktnih zuba (in vitro studija) izvađenih na Klinici za oralnu hirurgiju Univerzitetskog stomatološkog kliničkog centra St. Pantelejmon u Skoplju. DNK analize su sprovedene na Institutu za sudsku medicinu, kriminologiju i medicinsku deontologiju. Metod sa magnetnim česticama korišćen je kao čvrsta faza za vezivanje molekula DNK (Prepfiler Kit iz ABI"'). 
Ova tehnika izolacije DNK (za razliku od starog procesa organske izolacije) zasniva se na ekstrakciji čvrste faze (SPE). Ona koristi kolone napunjene silicijumom ili drugom čvrstom fazom koja selektivno veže (adsorbuje) nukleinske kiseline (DNK ili RNK) u zavisnosti od pH okoline i koncentracije soli u puferu (u našem slučaju čvrsta faza su bile magnetne čestice). Kolone i svi puferi korišćeni za izvođenje ove procedure dolaze u obliku komercijalnih kitova i postupak je izveden u skladu sa uputstvima proizvođača.

Kvantifikacija uzoraka obavljena je pomoću Qunatifiler DNA Quantification Kita (Applied Biosystems) na 7500 sistemu Real Time PCR. Ovaj pristup omogućava kvantifikaciju DNK $\mathrm{u}$ inicijalnom uzorku merenjem fluorescentnih signala tokom amplifikacije ciljane sekvence. Primarni cilj PCR kvantifikacije u realnom vremenu je određivanje količine DNK koja može biti „amplificirana“ u uzorku. Ulazna količina Quantifiler ${ }^{\circledast}$ Duo Primer Mixa za kvantifikaciju jednog uzorka iznosila je 10,5 $\mu$ l, a ulazna količina Quantifiler ${ }^{\circledast}$ Duo PCR Reaction Mixa je bila $12,5 \mu$ l. Zapremina uzorka dodatog u reakciju za kvantifikaciju je bila $2 \mu$ l. Celokupni volumen reakcione mešavine iznosio je $25 \mu$ l.

Prva analiza je obuhvatila 30 zuba podeljenih u tri grupe od po 10 zuba: sekutići, premolari i molari. Postupak izolacije DNK iz zuba uključio je mlevenje zuba u blenderu i korišćenje komercijalizovanih kitova (izolacija magnetnim česticama). Ovim metodom zubi koji su prethodno bili podvrgnuti endodontskom tretmanu ne mogu se koristiti za izolaciju DNK [8]. Zubi su prvo ispirani vodom iz česme, a površina dobro očišćena skalpelom i četkom. Onda su zubi držani u ultrazvučnom kupatilu u $1 \%$ natrijum-hipohlorita $(\mathrm{NaOCl})$ dva puta po 10 minuta nakon zamene rastvora $\mathrm{NaOCl}$. Ovaj postupak je ponovljen i dva puta sa destilovanom vodom. Procedura čišćenja je trajala oko 40 minuta. Zubi su tada postavljeni u dasku za isparavanje kako bi se osušili preko noći. Osušenim zubima je prvo bila izmerena težina, a potom su samleveni u blenderu za male kosti i zube da bi se dobio zubni prah.

$\mathrm{U}$ drugom testu je korišćeno 15 zuba podeljenih u dve grupe. U prvoj grupi je DNK izolovana iz pulpnog tkiva, a u drugoj grupi iz istih zuba je korišćeno čvrsto zubno tkivo za izolaciju DNK. Pulpa je kolektovana pomoću nervnih ekstirpatora nakon izvršenog horizontalnog preseka zuba. Ovaj postupak horizontalnog presecanja zuba u liniji vrata zuba obavljen je kako bi se očuvala okluzalna površina zuba koja je mogla poslužiti za dalju proceduru identifikacije. Ovo razdvajanje je obavljeno korišćenjem dijamantskih borera i mikromotora. Kružnim pokretima diska polako je presecan zub u nivou vrata. Kad je disk bio blizu pulpne komore, zubi su prelomljeni, kako bi se izbeglo pregrevanje i mehaničko oštećenje tkiva pulpe, ali i kontaminacija materijala.

\section{REZULTATI}

U prvom testu su analizirane različite grupe zuba, sveže izvađenih sekutića, premolara i molara. To su tri grupe koje se razlikuju po veličini i broju korena, tj. postoje velike morfološke razlike među njima. Rezultati su prikazani u Tabelama 1-3.

U drugom testu su upoređene količine DNK dobijene iz pulpe i tvrdih zubnih tkiva. Rezultati su prikazani u Tabelama 4 i 5.

\section{DISKUSIJA}

U forenzičkim slučajevima identifikacije, gde su ljudski ostaci izuzetno oštećeni ili degradirani, zubi i kosti su često jedini izvor DNK $[9,10]$. Genetska analiza zuba zavisi od količine prisutne DNK, nivoa degradacije i efikasnosti procesa kolekcije DNK i metoda koji se koriste za izolaciju DNK [11]. Sa trenutnim saznanjima o strukturi zuba i degradacije DNK u zubnom tkivu posle smrti, naš rad nudi optimalan izbor zuba, kako bi se povećala efikasnost ekstrakcije i profiliranja DNK.

Može se videti da je najveća količina DNK dobijena u grupi molara i to $0,230011 \mathrm{ng} / \mu \mathrm{l} / \mathrm{g}$ zuba, dok je u grupi sekutića dobi-

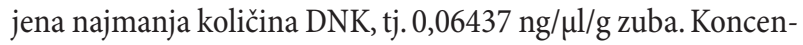
tracija izolovane DNK iz grupe molara bila je četiri puta veća od grupe premolara i pet puta veća od grupe sekutića. Međusobno upoređivanje grupe premolara i sekutića pokazalo je približno iste vrednosti koncentracije izolovane DNK, sa malo većom količinom u grupi premolara. Ovo se može objasniti činjenicom da premolari pokazuju velike varijacije u veličini krune i broju korena (jedan ili dva korena). Pozitivna korelacija je utvrđena između težine zuba i količine izolovane DNK. Najmanju težinu imali su sekutići, sa prosekom od 0,605 g, i dali su najmanju količinu izolovane DNK. Premolari su imali prosečno 0,892 g i dali su veću količinu DNK, a molari sa prosečnom masom 1,705 g dali su najveću količinu DNK. Druge studije koje su takođe upoređivale količinu DNK između različitih vrsta zuba pokazale su da su zubi sa najvećom količinom zubnog tkiva najbolji izvor DNK $[11,7]$. Takođe je potvrđeno da se veća količina DNK može dobiti od zuba sa više korena i to je zbog veće površine korena, koja obezbeđuje veću količinu cementa [11].

Zubi sa više korenova ne samo što imaju veću površinu korena kao i veću količinu pulpnog tkiva u kome se nalaze odontoblasti i cementociti već pokazuju i više ćelijskog cementa u poređenju sa drugim grupama zuba, koji u nekim slučajevima imaju malo ili nimalo ćelijskog cementa. Prema tome, molari bi bili najbolji izbor zuba za uzorkovanje DNK zbog najveće površine korena. U odsustvu molara premolari se preporučuju za izolaciju DNK, jer imaju veću količinu ćelijskog cementa nego prednji zubi, mada očnjaci imaju veći volumen pulpe. Veća količina ćelijskog cementa pruža veći broj cementocita, ćelija koje su glavni izvor DNK.

U drugom delu studije pokazano je da je količina DNK dobijene iz pulpe značajno veća od količine DNK dobijene iz zubnih tvrdih tkiva. Količina DNK dobijene iz pulpe, po različitim grupama zuba, pokazala je da grupa molara kvantitativno obezbeđuje najveću količinu DNK. Pulpno tkivo molara ima zapravo najveći broj ćelija koje su glavni izvor DNK (Tabela 5).

Količina DNK dobijena iz pulpnog kompleksa tri različite grupe zuba pokazala je da molari imaju najveću količinu DNK. To je očekivano, pošto je zapremina pulpne komore kod molara najveća. Grupa premolara i sekutića obezbedila je sličnu količinu izolovane DNK, koja je bila šest puta manja nego u grupi molara. Slično tome, količina DNK izolovane iz tvrdih zubnih tkiva značajno je bila veća u grupi molara nego u druge dve grupe (premolari i sekutići), koje su pokazale sličnu količinu DNK. Upoređivanje količine izolovane DNK (ng/ $\mathrm{l} / \mathrm{g}$ ) iz pulpe i tvrdih zubnih tkiva pokazalo je da pulpa daje 85 puta veću količinu DNK.

Pulpodentinski kompleks predstavlja najveći deo zuba i za razliku od gleđi predstavlja visokokompleksno ćelijsko tkivo. Pulpa je bogato vaskularizovano i inervirano vezivno tkivo koje sadrži 
različite vrste ćelija. Tu se nalaze odontoblasti (ćelije koje proizvode dentin), fibroblasti, odbrambene ćelije (makrofagi i histociti), plazma ćelije, nervne ćelije, nediferencirane mezenhimalne ćelije [12]. Znajući da je oko 80 diploidnih ćelija dovoljno da obezbede minimalnu količinu DNK potrebnu za STR mapiranje, može se zaključiti da je pulpa izuzetno vredan izvor DNK. Pulpno tkivo je $\mathrm{u}$ vezi sa periodontalnim tkivima (tkiva koja povezuju bilo koji zub sa alveolarnom kosti) preko vrha korena i pomoćnih kanala [13].

\section{ZAKLJUČAK}

Pulpno tkivo i cement su najvredniji izvori nuklearne DNK iz zuba. Gleđ štiti dentin i pulpu, ali nema DNK. Glavno tkivo koje treba koristiti za izolaciju DNK je pulpa, ali u onim slučajevima u kojima nije prisutna (endodontski tretman) tvrda zubna tkiva daju dovoljnu količinu DNK za postupke identifikacije. Grupa zuba koja pruža najveću količinu DNK su molari. 